\title{
Review Article \\ Review on the Risk Assessment of Heavy Metals in Malaysian Clams
}

\author{
Md. Faruk Hossen, Sinin Hamdan, and Md. Rezaur Rahman \\ Faculty of Engineering, Universiti Malaysia Sarawak, 94300 Kota Samarahan, Sarawak, Malaysia \\ Correspondence should be addressed to Md. Faruk Hossen; fhossen.chem@gmail.com
}

Received 18 February 2015; Revised 7 April 2015; Accepted 14 April 2015

Academic Editor: Jorge R. Ruelas-Inzunza

Copyright ( $2015 \mathrm{Md}$. Faruk Hossen et al. This is an open access article distributed under the Creative Commons Attribution License, which permits unrestricted use, distribution, and reproduction in any medium, provided the original work is properly cited.

The current review discusses the levels of six heavy metals in different clam species from 34 sites of Malaysian coasts. The concentrations $(\mu \mathrm{g} / \mathrm{g}$ dry weight) of these heavy metals ranged around $0.18-8.51,0.13-17.20,2.17-7.80,0.84-36.00,24.13-368.00$, and 177.82-1912.00 for $\mathrm{Cd}, \mathrm{Pb}, \mathrm{Ni}, \mathrm{Cu}, \mathrm{Zn}$, and $\mathrm{Fe}$, respectively. It was observed that the concentrations of metals slightly depend on different clam species but mostly depend on site locations. According to Malaysian Food Regulation (1985), about 30\% and more than $50 \%$ sites are safe from $\mathrm{Cd}$ and $\mathrm{Pb}$ contamination, respectively, and also the clam species from the other populations studied were safe for consumption.

\section{Introduction}

Heavy metals pollution has been a hot issue in marine environmental studies for many years. Even though metals occur naturally in the environment, due to the anthropogenic inputs which originate from various human activities the concentrations have been rising [1-3]. Increased coastal population, rapid urbanization, oil and gas production, tourism development, heavy rainfall throughout the year, and various economic activities have created numerous environmental and ecological problems in Malaysia's coastal areas, including beach erosion, resource depletion and environmental degradation, and destruction of natural habitats [4-7]. Bivalve mollusks such as clams, oyster, and cockles are found on the mangrove mudflats and intertidal sandy beaches and are wellknown accumulator of heavy metals and have been widely used as bioindicator for monitoring heavy metal pollution in aquatic environment in Malaysian coasts [3, 5, 8-13].

According to the Department of Fisheries Malaysia (2005), in 2005-2006, the Malaysia Fisheries Directory documented that there are approximately 27 species of bivalves in Malaysian coastal areas. Clams like other marine bivalves are benthic filter feeders; they are a potential biomonitor of the bioavailability of toxic metal contamination in the estuary [14]. These animals ingest metal-enriched particles directly, thereby giving an indication of the bioaccumulation ability of metals $[15,16]$. The increases in anthropogenic activities contribute to the accumulation of hazardous chemicals, such as heavy metals, in the environment $[3,9,17]$. Heavy metal discharged into the environment rapidly associates with particulates and ultimately settles in bottom sediments of water bodies, either direct discharge or surface run-offs [18]. Most of the living organisms need small amount of essential metals such as $\mathrm{Fe}, \mathrm{Mn}, \mathrm{Cu}$, and $\mathrm{Zn}$ for essential processes such as growth $[12,19]$. However, all these metals will give harmful effects when exceeding the standard limits [20]. The nonessential metals such as $\mathrm{Cd}, \mathrm{Pb}, \mathrm{Ni}$, and $\mathrm{Cr}$ are toxic even at relatively low concentration and not essential for metabolic activities [12, 21]. The abundance of heavy metal may jeopardize human health due to the consumption of contaminated bivalves [3]. For examples, $\mathrm{Cd}$ may cause human carcinogen; $\mathrm{Pb}$ can damage blood circulation and excessive intake of $\mathrm{Zn}$ may cause electrolyte imbalance and lethargy [22-24].

The main objective in this review is to study the concentration of heavy metal in clam species from different coasts of Malaysia. In this study, heavy metals $(\mathrm{Cd}, \mathrm{Pb}, \mathrm{Ni}, \mathrm{Cu}, \mathrm{Zn}$, and $\mathrm{Fe}$ ) in 12 clam species from 34 sites of Malaysian coasts have 


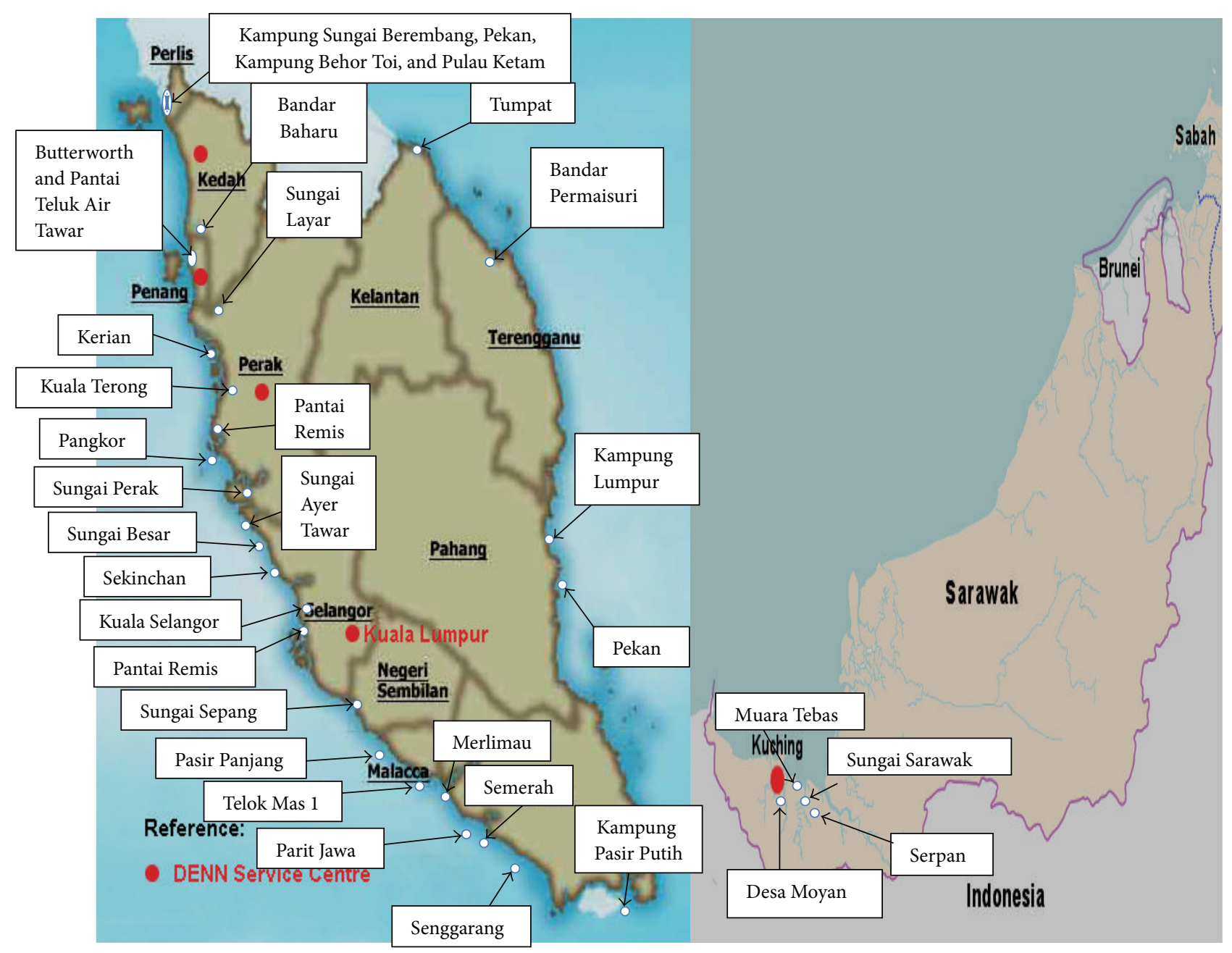

FIGURE 1: Map of Malaysian coasts showing sampling sites.

been considered and an assessment of human health risks has been conducted comparing those with the food criteria set by different countries.

\section{Discussion}

The heavy metals such as $\mathrm{Cd}, \mathrm{Pb}$, As, and $\mathrm{Hg}$ are known as nonessential metals. They are toxic even in small amount and harmful to human health. Harmful metals released by the human activities will be accumulated in marine organisms through the food web. Hence, human health risks might be caused by consumption of seafood contaminated by toxic metals. Normally, human body requires some of heavy metals such as $\mathrm{Cu}, \mathrm{Zn}, \mathrm{Fe}$, and $\mathrm{Ni}$ although sometimes $\mathrm{Ni}$ acts as toxic metal. These metals are known as essential metals. However, the essential metals can be toxic if taken in large quantities $[20,25,26]$. In this study, heavy metals such as $\mathrm{Cd}, \mathrm{Pb}, \mathrm{Ni}$, $\mathrm{Cu}, \mathrm{Zn}$, and $\mathrm{Fe}$ in total soft tissues of 12 clam species from 34 sites (Figure 1) of Malaysian coasts have been discussed.

2.1. Cadmium. It was observed that the range of $\mathrm{Cd}$ concentration was $0.18-8.51 \mu \mathrm{g} / \mathrm{g}$ (dry weight) in different clam species from different coasts of Malaysia (Table 1). The highest value was observed in Scapharca broughtonii from Pantai Remis (Perak), while the lowest value was observed in Anadara granosa from Tumpat (Kelantan). The Cd levels in clam species from most of the sites exceeded the maximum permissible limits set by Malaysian Food Regulation (1985) and ICES (1988) but the species from Bandar Baharu (Kedah), Merlimau (Malacca), Semerah (Johor), Tumpat (Kelantan), Pekan and Tanjung Lumpur (Pahang), Bandar Permaisuri (Terengganu), and Desa Moyan and Serpan (Sarawak) exhibited lower values than safety limits. Only three species from Kampung Sungai Berembang and Pulau Ketam, Perlis, and Pantai Remis, Perak, exceeded the maximum permissible limit set by Brazilian Ministry of Health (ABIA, 1991) but were lower than the permissible limits for human consumption set by Food and Drug Administration of the United States (USFDA, 1990) and the Australian Legal Requirements for Food Safety (NHMRC, 1987) (Table 2). However, it was observed that $\mathrm{Cd}$ in clam species from six sites is within the lowest safety limits $(1.01-2.00 \mu \mathrm{g} / \mathrm{g})$ set by Malaysian Food Regulation (1985), International Council for the Exploration of the Seas (ICES, 1988), and Hong Kong Environmental 
TABLE 1: Mean concentration of metals ( $\mu \mathrm{g} / \mathrm{g}$ dry weight) in total soft tissue of different clam species from Malaysia.

\begin{tabular}{|c|c|c|c|c|c|c|c|c|}
\hline Locations & Clam species & $\mathrm{Cd}$ & $\mathrm{Pb}$ & $\mathrm{Ni}$ & $\mathrm{Cu}$ & $\mathrm{Zn}$ & $\mathrm{Fe}$ & References \\
\hline \multicolumn{9}{|l|}{ Perlis } \\
\hline Kampung Sungai Berembang & Glauconome virens & - & - & 1.25 & 8.76 & 74.62 & 572.60 & {$[15]$} \\
\hline Pekan & Marcia marmorata & 3.40 & - & - & 22.80 & 88.70 & - & \multirow{4}{*}[3]{} \\
\hline Kampung Behor Toi & Marcia marmorata & 1.90 & - & - & 14.90 & 77.50 & - & \\
\hline Kampung Sungai Berembang & Marcia marmorata & 7.10 & - & - & 23.90 & 89.70 & - & \\
\hline Pulau Ketam & Marcia marmorata & 5.20 & - & - & 24.70 & 116.50 & - & \\
\hline \multicolumn{9}{|l|}{ Kedah } \\
\hline Bandar Baharu & Anadara granosa & 0.67 & 0.16 & - & 2.01 & 57.20 & - & {$[5]$} \\
\hline Sungai Layar & Glauconome virens & - & - & 2.19 & 11.05 & 119.28 & 706.60 & {$[15]$} \\
\hline \multicolumn{9}{|l|}{ Penang } \\
\hline Butterworth & Anadara granosa & 3.43 & 1.08 & - & 3.27 & 98.79 & - & {$[5]$} \\
\hline Pantai Teluk Air Tawar & Glauconome virens & - & - & 2.05 & 11.02 & 132.06 & - & {$[15]$} \\
\hline \multicolumn{9}{|l|}{ Perak } \\
\hline Kerian & Anadara granosa & 2.60 & 0.92 & - & 1.67 & 56.43 & - & \multirow{6}{*}{ [5] } \\
\hline Kuala Terong & Anadara granosa & 2.49 & 0.93 & - & 3.18 & 77.21 & - & \\
\hline Pangkor & Anadara granosa & 2.14 & 0.79 & - & 2.42 & 73.41 & - & \\
\hline Sungai Perak & Anadara granosa & 1.49 & 1.33 & - & 2.57 & 69.82 & - & \\
\hline Pantai Remis & Scapharca broughtonii & 8.51 & 19.10 & 5.26 & 4.54 & 67.80 & 782.00 & \\
\hline Pantai Remis & Trisidos kiyonoi & 2.64 & 8.00 & 4.93 & 5.84 & 61.50 & 501.00 & \\
\hline \multicolumn{9}{|l|}{ Selangor } \\
\hline Sungai Ayer Tawar & Anadara granosa & 2.67 & 1.78 & - & 3.07 & 136.03 & - & \multirow{3}{*}[5]{} \\
\hline Sungai Besar & Anadara granosa & 4.43 & 1.61 & - & 2.17 & 158.00 & - & \\
\hline Kuala Selangor & Anadara granosa & 2.66 & 3.04 & - & 2.94 & 99.70 & - & \\
\hline Sekinchan & Pholas orientalis & 2.31 & 3.96 & 2.17 & 16.86 & 40.43 & 291.15 & \multirow{2}{*}[10]{} \\
\hline Pantai Remis & Pholas orientalis & 1.75 & 8.21 & 6.17 & 22.55 & 37.76 & 292.75 & \\
\hline Sungai Sepang & Polymesoda erosa & 2.96 & 6.80 & 5.07 & 15.70 & 343.00 & 1111.00 & {$[6]$} \\
\hline \multicolumn{9}{|l|}{ Negeri Sembilan } \\
\hline Pasir Panjang & Donax faba & 3.96 & 12.60 & 3.65 & 7.23 & 51.20 & 654.00 & {$[6]$} \\
\hline \multicolumn{9}{|l|}{ Malacca } \\
\hline Merlimau & Anadara granosa & 0.62 & 0.91 & - & 9.10 & 98.72 & - & {$[5]$} \\
\hline Telok Mas 1 & Polymesoda erosa & 4.23 & 11.60 & 4.29 & 5.91 & 249.00 & 1912.00 & {$[6]$} \\
\hline \multicolumn{9}{|l|}{ Johor } \\
\hline Semerah & Anadara granosa & 0.82 & 1.43 & - & 1.96 & 53.22 & - & \multirow{2}{*}[5]{} \\
\hline Senggarang & Anadara granosa & 1.45 & 0.60 & - & 2.67 & 65.91 & - & \\
\hline Parit Jawa & Polymesoda erosa & 3.34 & 12.20 & 7.80 & 6.50 & 222.00 & 1307.00 & \multirow{2}{*}[6]{} \\
\hline Kampung Pasir Putih & Polymesoda expansa & 3.59 & 17.20 & 6.04 & 36.00 & 368.00 & 1454.00 & \\
\hline \multicolumn{9}{|l|}{ Kelantan } \\
\hline Tumpat & Anadara granosa & 0.18 & 0.99 & - & 1.84 & 41.80 & - & {$[5]$} \\
\hline \multicolumn{9}{|l|}{ Pahang } \\
\hline Pekan & Anadara granosa & 0.65 & 0.13 & - & 4.92 & 104.02 & - & {$[5]$} \\
\hline Tanjung Lumpur & Solen brevis & 0.67 & 1.61 & - & 8.64 & 87.74 & 415.20 & {$[11]$} \\
\hline \multicolumn{9}{|l|}{ Terengganu } \\
\hline Bandar Permaisuri & Anadara granosa & 0.35 & 0.45 & - & 2.19 & 64.50 & - & {$[5]$} \\
\hline \multicolumn{9}{|l|}{ Sarawak } \\
\hline Muara Tebas & Solen spp. & 1.64 & 13.47 & - & 4.11 & 82.82 & 522.07 & {$[1]$} \\
\hline Desa Moyan & Solen regularis & 0.85 & - & - & 6.75 & - & 263.50 & \multirow{2}{*}{ [2] } \\
\hline Serpan & Solen regularis & 0.88 & - & - & 8.05 & - & 601.25 & \\
\hline Sungai Sarawak & Polymesoda expansa & 1.15 & 2.89 & - & 0.84 & 62.24 & 295.31 & \\
\hline Sungai Sarawak & Meretrix meretrix & 2.15 & 2.23 & - & 1.57 & 24.13 & 250.73 & {$[13]$} \\
\hline Sungai Sarawak & Solen regularis & 2.35 & 4.85 & - & 2.21 & 27.08 & 177.82 & \\
\hline
\end{tabular}


TABLE 2: Guidelines on heavy metals ( $\mu \mathrm{g} / \mathrm{g}$ dry weight) for food safety set by different countries [27-38].

\begin{tabular}{|c|c|c|c|c|c|c|}
\hline Countries & $\mathrm{Cd}$ & $\mathrm{Cu}$ & $\mathrm{Pb}$ & $\mathrm{Zn}$ & $\mathrm{Ni}$ & $\mathrm{Fe}$ \\
\hline Malaysian Food Regulation (1985) & 1.00 & 30.0 & 2.00 & 100.00 & - & - \\
\hline International Council for the Exploration of the Seas (ICES, 1988) & 1.80 & - & 3.00 & - & - & - \\
\hline Brazilian Ministry of Health (ABIA, 1991) & 5.00 & 150 & 10.0 & 250.00 & - & - \\
\hline Ministry of Public Health, Thailand (MPHT, 1986) & - & 133 & 6.67 & 667.00 & - & - \\
\hline Food and Drug Administration of the United States (USFDA, 1990) & 25.0 & - & 11.50 & - & - & - \\
\hline Australian Legal Requirements for Food Safety (NHMRC, 1987) & 10.0 & 350 & - & 750.00 & - & - \\
\hline Hong Kong Environmental Protection Department (HKEPD, 1997) & 2.00 & - & 6.00 & - & - & - \\
\hline
\end{tabular}

Protection Department (HKEPD, 1997) while Cd in clams from 17 sites is within the 2nd highest safety limits (2.01$5.00 \mu \mathrm{g} / \mathrm{g}$ ) set by Brazilian Ministry of Health (ABIA, 1991). On the other hand, only three species from Kampung Sungai Berembang (Perlis), Pulau Ketam (Perlis), and Pantai Remis (Perak) are within the highest safety limits (5.01-10.00 $\mu \mathrm{g} / \mathrm{g}$ ) set by the Australian Legal Requirements for Food Safety (NHMRC, 1987).

2.2. Lead. The concentrations of $\mathrm{Pb}$ range from 0.13 to $19.10 \mu \mathrm{g} / \mathrm{g}$ (dry weight) (Table 1). The highest value was observed in Scapharca broughtonii from Pantai Remis (Perak), while the lowest value was observed in Anadara granosa from Pekan (Pahang). The $\mathrm{Pb}$ levels in clams from 14 sites exceeded the maximum permissible limits set by Malaysian Food Regulation (1985) and International Council for the Exploration of the Seas (ICES, 1988) while species from 9 sites exceeded the maximum permissible limits set by Brazilian Ministry of Health (ABIA, 1991) and Ministry of Public Health, Thailand (MPHT, 1986). But six clam species from Pantai Remis (Perak), Pasir Panjang (Negeri Sembilan), Telok Mas 1 (Malacca), Parit Jawa and Kampung Pasir Putih (Johor), and Muara Tebas (Sarawak) exceeded all of the maximum permissible limits (Table 2). However, it was observed that $\mathrm{Pb}$ levels in clams from more than $50 \%$ sites are below the safety limits (Table 1) but in Sungai Sarawak (Sarawak) and Sekinchan and Kuala Selangor (Selangor) are within the lowest safety limits $(2.01-6.00 \mu \mathrm{g} / \mathrm{g})$ set by Malaysian Food Regulation (1985), International Council for the Exploration of the Seas (ICES, 1988), and Hong Kong Environmental Protection Department (HKEPD, 1997) and only in three species from Pantai Remis (Selangor), Sungai Sepang (Selangor), and Pantai Remis (Perak) are within the highest safety limits $(6.01-11.50 \mu \mathrm{g} / \mathrm{g})$ set by Ministry of Public Health, Thailand (MPHT, 1986), Food and Drug Administration of the United States (USFDA, 1990), and Brazilian Ministry of Health (ABIA, 1991) while that from 6 sites mentioned earlier exceeded all of those safety limits (Table 2).

2.3. Nickel. Nickel normally occurs at very low concentrations in the environment. It was observed that the range of $\mathrm{Ni}$ was $1.25-7.80 \mu \mathrm{g} / \mathrm{g}$ (dry weight) in different clam species from different coasts of Malaysia (Table 1). The highest value was observed in Polymesoda erosa from Parit Jawa, Johor, and the lowest value was observed in Pholas orientalis from Sekinchan, Selangor. Ni in clams from Sungai Sepang (Selangor),
Pantai Remis (Selangor), Kampung Pasir Putih (Johor), Parit Jawa (Johor), and Pantai Remis (Perak) were higher than $5.00 \mu \mathrm{g} / \mathrm{g}$.

2.4. Copper. Copper is an essential element for human health. The range of $\mathrm{Cu}$ concentration was $0.84-36.00 \mu \mathrm{g} / \mathrm{g}$ (dry weight) in different clam species from different coasts of Malaysia (Table 1). The highest value was observed in Polymesoda expansa from Kampung Pasir (Johor) and the lowest value was observed in the same species from Sungai Sarawak (Sarawak). The $\mathrm{Cu}$ levels from all of the sites were below the maximum permissible limits set by Malaysian Food Regulation (1985), Ministry of Public Health, Thailand (MPHT, 1986), Australian Legal Requirements for Food Safety (NHMRC, 1987), International Council for the Exploration of the Seas (ICES, 1988), Food and Drug Administration of the United States (USFDA, 1990), and Brazilian Ministry of Health (ABIA, 1991) while $\mathrm{Cu}$ in the same ones from Kampung Pasir Putih (Johor) exceeded the maximum permissible limits set by Malaysian Food Regulation (1985) (Table 2).

2.5. Zinc. Zinc is also an essential element like copper. It was observed that the $\mathrm{Zn}$ concentrations in different clam species from different coasts of Malaysia ranged widely from 24.13 to $368.00 \mu \mathrm{g} / \mathrm{g}$ (dry weight) (Table 1). The highest value was observed in Polymesoda expansa from Kampung Pasir Putih (Johor), while the lowest value was observed in Meretrix meretrix from Sungai Sarawak (Sarawak). The Pb levels of clam species from almost 10 sites exceeded the maximum permissible limits set by Malaysian Food Regulation (1985) and only Polymesoda erosa and Polymesoda expansa from Sungai Sepang, Selangor, and Kampung Pasir, Johor, respectively, exceeded the second highest maximum permissible limits set by Brazilian Ministry of Health (ABIA, 1991) but Zn levels from all of those sites were below the highest maximum permissible limits set by Ministry of Public Health, Thailand (MPHT, 1986), and Australian Legal Requirements for Food Safety (NHMRC, 1987) (Table 2).

However, $\mathrm{Zn}$ value in clams from 6 sites was within the lowest safety limits $(100.01-250.00 \mu \mathrm{g} / \mathrm{g})$ set by Malaysian Food Regulation (1985) and Brazilian Ministry of Health (ABIA, 1991) while $\mathrm{Zn}$ in clams only from Kampung Pasir (Johor) and Sungai Sepang (Selangor) was above this lowest safety limit but below the highest safety limits (667.01$750.00 \mu \mathrm{g} / \mathrm{g})$. 
2.6. Iron. Iron is an essential nutrient metal required for human. It was observed that the Fe concentration ranged widely from 177.82 to $1912.00 \mu \mathrm{g} / \mathrm{g}$ (dry weight) in different clam species from different coasts of Malaysia (Table 1). The highest value was observed in Polymesoda erosa from Telok Mas 1 (Malacca), while the lowest value was observed in Solen regularis from Sungai Sarawak (Sarawak). However, very high values of $\mathrm{Fe}$ were observed in clams from Telok Mas 1 (Malacca), Kampung Pasir (Johor), Parit Jawa (Johor), and Sungai Sepang (Selangor) which were 1912, 1454, 1307, and $1111, \mu \mathrm{g} / \mathrm{g}$ respectively.

\section{Health Risk Assessment}

In this study, an assessment on human health risks has been conducted by comparing the levels of the heavy metals found in the total soft tissues of clam species (Table 1) with the food criteria set by different countries (Table 2).

Cadmium is one of the environmental contaminants which can promote serious damage to human health. It was observed that Cd levels within the lowest safety limits (1.01$2.00 \mu \mathrm{g} / \mathrm{g}$ ) may be due to the fact that most of those samples sites were within the vicinity of agricultural areas of mostly large oil palm plantations heavy in pesticides and herbicides used $[2,5]$ while the levels are within the 2 nd highest safety limits $(2.01-5.00 \mu \mathrm{g} / \mathrm{g})$. On the other hand, Cd levels within the highest safety limits $(5.01-10.00 \mu \mathrm{g} / \mathrm{g})$ may be due to the influence of external discrete sources like industrial activities, agriculture runoff, and other anthropogenic inputs [3,39]. From this study, it is revealed that Cd may cause possible toxicological risks and heavy metal related diseases, such as Parkinson's and Wilson's diseases [40] due to long term consumption especially for the population of Kampung Sungai Berembang (Perlis), Pulau Ketam (Perlis), and Pantai Remis (Perak).

Lead is also one of the environmental contaminants. It was observed that $\mathrm{Pb}$ levels in clam species from more than $50 \%$ sites are below the safety limits (Table 1) but those from Sungai Sarawak (Sarawak) and Sekinchan and Kuala Selangor (Selangor) are within the lowest safety limits (2.01-6.00 $\mu \mathrm{g} / \mathrm{g}$ ) which indicated that these sites are slightly polluted. Only three species from Pantai Remis (Selangor), Sungai Sepang (Selangor), and Pantai Remis (Perak) are within the highest safety limits (6.01-11.50 $\mu \mathrm{g} / \mathrm{g}$ ) set while Pb levels in clams from 6 sites mentioned earlier exceeded all of those safety limits (Table 2) and this maybe resulted from burning of fossil fuels from boats used for fishing and also leisure activities $[1,6]$. This may be the cause of neurological deficits such as mental retardation in children and kidney disease such as interstitial nephritis to adults and also contribute to hypertension and cardiovascular disease [41] to the consumers in these coastal areas after long term consumption.

Nickel normally occurs at very low concentrations in the environment and it can cause variety of pulmonary adverse health effects [42]. The levels of Ni in clams from Sungai Sepang (Selangor), Pantai Remis (Selangor), Kampung Pasir (Johor), Parit Jawa (Johor), and Pantai Remis (Perak) were higher than $5.00 \mu \mathrm{g} / \mathrm{g}$ (Table 1). The cause may be that human activities such as metal mining, smelting, refining, fossil fuel combustion, and solid waste disposal are the significant sources of this metal discharge to the environment and large amount may be transferred to marine environment through municipal sewage effluent containing industrial waste $[6,15$, 43]. Ni has no definite safety limits but high values may lead to serious health problems, including respiratory system cancer, and it can also cause a skin disorder known as nickel-eczema [44].

Copper is an essential nutrient and is necessary for the synthesis of hemoglobin [45] and its deficiency can result in blood and nervous system disorders [46]. It was observed that $\mathrm{Cu}$ in clams from all sites was below the safety limits (Table 1) indicating that it should not pose an acute toxicological risk to the consumers. But $\mathrm{Cu}$ only in Polymesoda expansa from Kampung Pasir, Johor, exceeded the maximum permissible limits set by Malaysian Food Regulation (1985) (Table 2). This higher value may come from the paddy field activities where pesticides are used to prevent the insects' attack $[3,6]$ and can cause liver and kidney disease [47] and it may lead to stunted human growth due to long term consumption [48].

Zinc is also an important metal in human nutrition and fulfills many biochemical functions in human metabolism. Zn deficiency in human organism leads to several disorders, but an excessive $\mathrm{Zn}$ intake can cause acute adverse effects [49]. However, $\mathrm{Zn}$ value in calms from 6 sites is within the lowest safety limits (100.01-250.00 $\mu \mathrm{g} / \mathrm{g})$ indicating that these sites may be close to boating activities, fish landing, restaurants, and sightseeing view place [3], while Zn in clams only from Kampung Pasir (Johor) and Sungai Sepang (Selangor) is above the lowest safety limit but below the highest safety limits $(667.01-750.00 \mu \mathrm{g} / \mathrm{g})$. This may be from antifouling paint and incidental discharges of fuel, oil from boats, ship, and also municipal sewage [50], because $\mathrm{Zn}$ has been used as an anticorrosion agent and its ability to get speedy oxidation might enhance the level of zinc in these two sites. This will lead to a tendency in the organism to accumulate the high amount of $\mathrm{Zn}$ in its soft tissue [11]. In addition these sites are all in the vicinity of ports busy with navigational activities and cargo handling particularly petroleum and petroleum products [5]. Thus, high levels of zinc result in decreased cytochrome oxidase activity in the heart and liver as well as catalase in the liver [51] due to long term consumption.

Iron is an essential nutrient metal required for human but its deficiency is frequently associated with anemia [27, 28]. Smelting and refining of metals, steel manufacturing, and metal plating that mobilized iron by human activities may lead to the Fe contamination in marine environment [43]. However, very high values of $\mathrm{Fe}$ were observed in clams from Telok Mas 1 (Malacca), Kampung Pasir (Johor), Parit Jawa (Johor), and Sungai Sepang (Selangor) which were 1912, 1454,1307 , and $1111 \mu \mathrm{g} / \mathrm{g}$, respectively [6]. It has no definite safety limits like other metals but very high values due to the tendency of Fe to bind with organic matter in marine environment $[29,30]$ and also from those human activities.

In this study, it was found that the levels of metal slightly depend on species (Table 1). It was evidenced that different organisms display a range of capacities for the accumulation of metals, varying from accumulators to accumulators of certain elements $[6,13,31-36]$. Although the bioavailability of 
contaminants in the environment is complicated issue which involves many chemical, physical, and biological factors [37, 38], the use of the soft tissues of different clam species might provide a better insight into the bioavailability of metals. On the other hand, it was observed that the levels of metal mostly depend on site locations (Table 1). However, according to Malaysian Food Regulation (1985), about 30\% sites are safe from Cd contamination while more than $50 \%$ sites are safe from $\mathrm{Pb}$ contamination.

\section{Conclusion}

In the present study, it was found that the clam species from different sites accumulated heavy metals at different concentrations. It was also observed that the concentrations of metals slightly depend on different clam species but mostly depend on site locations. The results revealed that the clams from mentioned sites have higher values than the food safety limits which should be avoided in order to avoid any possible toxicological risks and heavy metal related diseases, such as Parkinson' disease, Wilson's disease, and Hallervorden-Spatz disease, due to long term consumption. On the other hand, according to Malaysian Food Regulation (1985), about 30\% and more than $50 \%$ sites are safe from $\mathrm{Cd}$ and $\mathrm{Pb}$ contamination, respectively, and also the clam species from the other populations studied were safe for consumption.

\section{Conflict of Interests}

The authors declare that there is no conflict of interests regarding the publication of this paper.

\section{Acknowledgments}

The authors wish to acknowledge the financial assistance provided through the Malaysian Government Research Grant no. ERGS/02(08)860/2012(12) and by the Universiti Malaysia Sarawak (UNIMAS).

\section{References}

[1] D. Kanakaraju, J. Connie, and S. M. Long, "Heavy metal concentrations in the razor clam (Solen Spp) from Muara Tebas, Sarawak," The Malaysian Journal of Analytical Sciences, vol. 12, no. 1, pp. 53-58, 2008.

[2] D. Kanakaraju, F. Ibrahim, and M. N. Berseli, "Comparative study of heavy metal concentrations in razor clam (Solen regularis) in Moyan and Serpan, Sarawak," Global Journal of Environmental Research, vol. 2, no. 2, pp. 87-91, 2008.

[3] L. Lias, T. Jamil, and S. N. Aliaa, "A preliminary study on heavy metal concentration in the marine bivalves Marcia marmorata species and sediments collected from the coastal area of Kuala Perlis, North of Malaysia," IOSR Journal of Applied Chemistry, vol. 4, no. 1, pp. 48-54, 2013.

[4] B. Cicin-Sain and R. W. Knecht, "Appendix 1: ICM practices in twenty-two selected nations, part II: middle developing nations, case study on Malaysia," in Integrated Coastal and Ocean Management: Concept and Practices, pp. 373-380, Island Press, Washington, DC, USA, 1998.
[5] A. M. Yusof, N. F. Yanta, and A. K. H. Wood, "The use of bivalves as bio-indicators in the assessment of marine pollution along a coastal area," Journal of Radioanalytical and Nuclear Chemistry, vol. 259, no. 1, pp. 119-127, 2004.

[6] F. B. Edward, C. K. Yap, A. Ismail, and S. G. Tan, "Interspecific variation of heavy metal concentrations in the different parts of tropical intertidal bivalves," Water, Air, and Soil Pollution, vol. 196, no. 1-4, pp. 297-309, 2009.

[7] M. Alina, A. Azrina, A. S. M. Yunus, S. M. Zakiuddin, H. M. I. Effendi, and R. M. Rizal, "Heavy metals (mercury, arsenic, cadmium, plumbum) in selected marine fish and shellfish along the straits of malacca," International Food Research Journal, vol. 19, no. 1, pp. 135-140, 2012.

[8] S. Lau, M. Mohamed, A. Tan Chi Yen, and S. Su'Ut, "Accumulation of heavy metals in freshwater molluscs," The Science of the Total Environment, vol. 214, no. 1-3, pp. 113-121, 1998.

[9] A. Ismail, "The use of intertidal molluscs in the monitoring of heavy metals and organotin compounds in the west coast of Peninsular Malaysia," Coastal Marine Science, vol. 30, no. 1, pp. 401-406, 2006.

[10] C. K. Yap, W. H. Cheng, A. Ismail, A. R. Ismail, and S. G. Tan, "Biomonitoring of heavy metal $(\mathrm{Cd}, \mathrm{Cu}, \mathrm{Pb}$, and $\mathrm{Zn})$ concentrations in the west intertidal area of Peninsular Malaysia by using Nerita lineata," Toxicological \& Environmental Chemistry, vol. 91, no. 1, pp. 29-41, 2009.

[11] B. Y. Kamaruzzaman, M. S. Zahir, A. B. John et al., "Determination of some heavy metal concentrations in razor clam (Solen brevis) from Tanjung Lumpur coastal waters, Pahang, Malaysia," Pakistan Journal of Biological Sciences, vol. 13, no. 24, pp. 12081213, 2010.

[12] B. Y. Kamaruzzaan, M. S. Zahir, B. A. John et al., "Bioaccumulation of some metals by Green mussel Perna viridis (Linnaeus 1758) from Pekan, Pahang, Malaysia," International Journal of Biological Chemistry, vol. 5, no. 1, pp. 54-60, 2011.

[13] N. A. M. Yusoff and S. M. Long, "Comparative bioaccumulation of heavy metals ( $\mathrm{Fe}, \mathrm{Zn}, \mathrm{Cu}, \mathrm{Cd}, \mathrm{Cr}, \mathrm{Pb}$ ) in different edible mollusk collected from the estuary area of Sarawak River," in Proceedings of the Universiti Malaysia Terengganu 10th International Annual Symposium (UMTAS '11), LSP136, 2011.

[14] S. N. Luoma and J. A. Davis, "Requirements for modeling trace metal partitioning in oxidized estuarine sediments," Marine Chemistry, vol. 12, no. 2-3, pp. 159-181, 1983.

[15] C. K. Yap, A. R. Kamarul, and F. B. Edward, "Heavy metal concentrations ( $\mathrm{Cd}, \mathrm{Cu}, \mathrm{Ni}, \mathrm{Pb}, \mathrm{Fe}$ and $\mathrm{Zn}$ ) in different soft tissues and shells of Pholas orientalis collected from Sekinchan and Pantai Remis, Selangor," Malaysian Applied Biology Journal, vol. 38, no. 1, pp. 21-27, 2009.

[16] C. K. Yap, S. M. R. Razeff, F. B. Edward, and S. G. Tan, "Heavy metal concentrations $(\mathrm{Cu}, \mathrm{Fe}, \mathrm{Ni}$ and $\mathrm{Zn})$ in the clam, Glauconome virens, collected from the northern intertidal areas of Peninsular Malaysia," Malaysian Applied Biology Journal, vol. 38, no. 1, pp. 29-35, 2009.

[17] S. G. Tuncel, S. Tugrul, and T. Topal, "A case study on trace metals in surface sediments and dissolved inorganic nutrients in surface water of Ölüdeniz Lagoon-Mediterranean, Turkey," Water Research, vol. 41, no. 2, pp. 365-372, 2007.

[18] A. K. Inengite, N. C. Oforka, and L. C. Osuji, "Survey of heavy metals in sediments of Kolocreek in the Niger Delta, Nigeria," African Journal of Environmental Science and Technology, vol. 4, no. 9, pp. 558-566, 2010.

[19] C. B. Ndome, U. B. Ekaluo, and F. E. Asuquo, "Comparative bioaccumulation of heavy metals ( $\mathrm{Fe}, \mathrm{Mn}, \mathrm{Zn}, \mathrm{Cu}, \mathrm{Cd} \& \mathrm{Cr}$ ) by 
some edible aquatic mollusc from the atlantic coastline of South Eastern Nigeria," World Journal of Fish and Marine Sciences, vol. 2, no. 4, pp. 317-321, 2010.

[20] H. Beldi, F. Gimbert, S. Maas, R. Scheifler, and N. Soltani, "Seasonal variations of $\mathrm{Cd}, \mathrm{Cu}, \mathrm{Pb}$ and $\mathrm{Zn}$ in the edible mollusc Donax trunculus (Mollusca, Bivalvia) from the gulf of Annaba, Algeria," African Journal of Agricultural Research, vol. 1, no. 4, pp. 85-90, 2006.

[21] L. J. de Astudillo, I. C. Chang Yen, and I. Bekele, "Heavy metals in sediments, mussels and oysters from Trinidad and Venezuela," International Journal of Tropical Biology, vol. 53, no. 1, pp. 41-53, 2005.

[22] IARC (International Agency for Research on Cancer), Cadmium and Cadmium Compounds, vol. 58 of IARC Monographs on the Evaluation of Carcinogenic Risks to Human, IARC, Lyon, France, 1993.

[23] M. S. Rahman, A. H. Molla, N. Saha, and A. Rahman, "Study on heavy metals levels and its risk assessment in some edible fishes from Bangshi River, Savar, Dhaka, Bangladesh," Food Chemistry, vol. 134, no. 4, pp. 1847-1854, 2012.

[24] N. Arnich, V. Sirot, G. Rivière et al., "Dietary exposure to trace elements and health risk assessment in the 2nd French Total Diet Study," Food and Chemical Toxicology, vol. 50, no. 7, pp. 2432-2449, 2012.

[25] M. Tüzen, "Determination of heavy metals in fish samples of the middle Black Sea (Turkey) by graphite furnace atomic absorption spectrometry," Food Chemistry, vol. 80, no. 1, pp. 119-123, 2003.

[26] Y. Keskin, R. Baskaya, O. Özyaral, T. Yurdun, N. E. Lüleci, and O. Hayran, "Cadmium, lead, mercury and copper in fish from the Marmara Sea, Turkey," Bulletin of Environmental Contamination and Toxicology, vol. 78, no. 3-4, pp. 258-261, 2007.

[27] International Council for the Exploration of the Seas (ICES), "Report of the working group on environmental impacts of mariculture," ICES CM 2012/SSGHIE:16, 1988.

[28] K. Schümann, T. Ettle, B. Szegner, B. Elsenhans, and N. W. Solomons, "On risks and benefits of iron supplementation recommendations for iron intake revisited," Journal of Trace Elements in Medicine and Biology, vol. 21, no. 3, pp. 147-168, 2007.

[29] ABIA (Associacão Brasileira das Indústrias de Alimentacão), Atos do Ministêrio da Saúde: Compêndio da Legislacão de Alimentos, 1991.

[30] WHO (World Health Organization), Iron, WHO Food Additives Series 18, World Health Organization, Geneva, Switzerland, 1983.

[31] MPHT (Ministry of Public Health. Thailand), Residues in Foods, vol. 103, part 23, The Government Gazette, Bangkok, Thailand, 1986.

[32] D. J. H. Phillips and P. S. Rainbow, "Strategies of trace metal sequestration in aquatic organisms," Marine Environmental Research, vol. 28, no. 1-4, pp. 207-210, 1989.

[33] Food and Drug Administration of the United States (USFDA), Shellfish Sanitation Branch, US Food and Drug Administration, Washington, DC, USA, 1990.

[34] D. J. H. Phillips, "The chemistries and environmental fates of trace metals and organochlorines in aquatic ecosystems," Marine Pollution Bulletin, vol. 31, no. 4-12, pp. 193-200, 1995.

[35] NHMRC (National Health and Medical Research Council), National Food Standard A 12: Metal and Contaminants in Food, Australia Government Publishing Services, Canberra, Australia, 1987.
[36] J. R. Ruelas-Inzunza and F. Páez-Osuna, “Comparative bioavailability of trace metals using three filter-feeder organisms in a subtropical coastal environment (Southeast Gulf of California)," Environmental Pollution, vol. 107, no. 3, pp. 437-444, 2000.

[37] HKEPD (Hong Kong Environmental Protection Department), Environment Hong Kong, Environmental Protection Department (EPD), Hong Kong, 1997.

[38] N. M. van Straalen, M. H. Donker, M. G. Vijver, and C. A. M. van Gestel, "Bioavailability of contaminants estimated from uptake rates into soil invertebrates," Environmental Pollution, vol. 136, no. 3, pp. 409-417, 2005.

[39] A. M. Rabee, Y. F. Al-Fatlawy, A. H. Najim, and M. Nameer, "Using Pollution Load Index (PLI) and Geoaccumulation Index (I-Geo) for the assessment of heavy metals pollution in Tigris river sediment in Baghdad Region," Journal of Al-Nahrain University, vol. 14, no. 4, pp. 108-114, 2011.

[40] E. B. Montgomery Jr., "Heavy metals and the etiology of Parkinson's disease and other movement disorders," Toxicology, vol. 97, no. 1-3, pp. 3-9, 1995.

[41] WHO (World Health Organization), Lead: International Programme on Chemical Safety (IPCS), WHO Food Additives Series 44, World Health Organization, Geneva, Switzerland, 2000.

[42] E. Forti, S. Salovaara, Y. Cetin et al., "In vitro evaluation of the toxicity induced by nickel soluble and particulate forms in human airway epithelial cells," Toxicology in Vitro, vol. 25, no. 2, pp. 454-461, 2011.

[43] A. Taweel, M. Shuhaimi-Othman, and A. K. Ahmad, "Assessment of heavy metals in tilapia fish (Oreochromis niloticus) from the Langat River and Engineering Lake in Bangi, Malaysia, and evaluation of the health risk from tilapia consumption," Ecotoxicology and Environmental Safety, vol. 93, pp. 45-51, 2013.

[44] M. C. Yebra, S. Cancela, and R. M. Cespón, "Automatic determination of nickel in foods by flame atomic absorption spectrometry," Food Chemistry, vol. 108, no. 2, pp. 774-778, 2008.

[45] P. Sivaperumal, T. V. Sankar, and P. G. V. Nair, "Heavy metal concentrations in fish, shellfish and fish products from internal markets of India vis-a-vis international standards," Food Chemistry, vol. 102, no. 3, pp. 612-620, 2007.

[46] M. H. Dabbaghmanesh, N. M. Salehi, J. Sidaan, and G. R. Omrani, "Copper concentration in a healthy urban adult population of southern Iran," Biological Trace Element Research, vol. 144, no. 1-3, pp. 217-224, 2011.

[47] J. M. Gorell, C. C. Johnson, B. A. Rybicki et al., "Occupational exposures to metals as risk factors for Parkinson's disease," Neurology, vol. 48, no. 3, pp. 650-658, 1997.

[48] M. Gorman, Environmental Hazards Marine Pollution, ABCCLIO, Santa Barbara, Calif, USA, 1993.

[49] H. Scherz and E. Kirchhoff, "Trace elements in foods: zinc contents of raw foods-a comparison of data originating from different geographical regions of the world," Journal of Food Composition and Analysis, vol. 19, no. 5, pp. 420-433, 2006.

[50] S. A. Waznah, B. Y. Kamaruzzaman, and S. Shahbudin, "Spatial and temporal variation of zinc $(\mathrm{Zn})$ and cadmium $(\mathrm{Cd})$ in the bottom sediments of Pahang river-estuary, Pahang, Malaysia," in Proceedings of the 10th Universiti Malaysia Terengganu International Annual Symposium (UMTAS '11), Kuala Terengganu, Malaysia, July 2011.

[51] WHO (World Health Organization), Zinc, WHO Food Additives Series 17, World Health Organization, Geneva, Switzerland, 1973. 

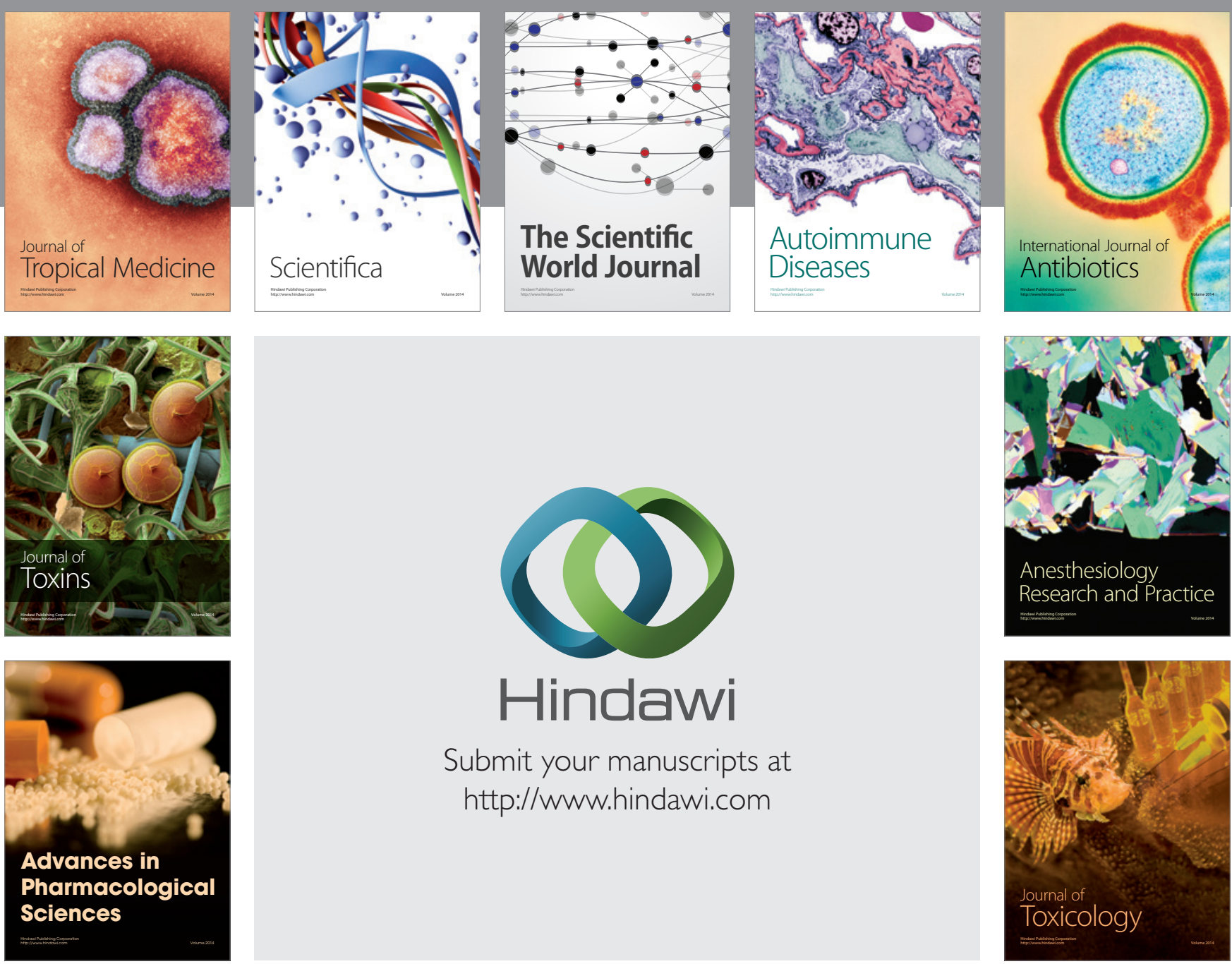

\section{Hindawi}

Submit your manuscripts at

http://www.hindawi.com
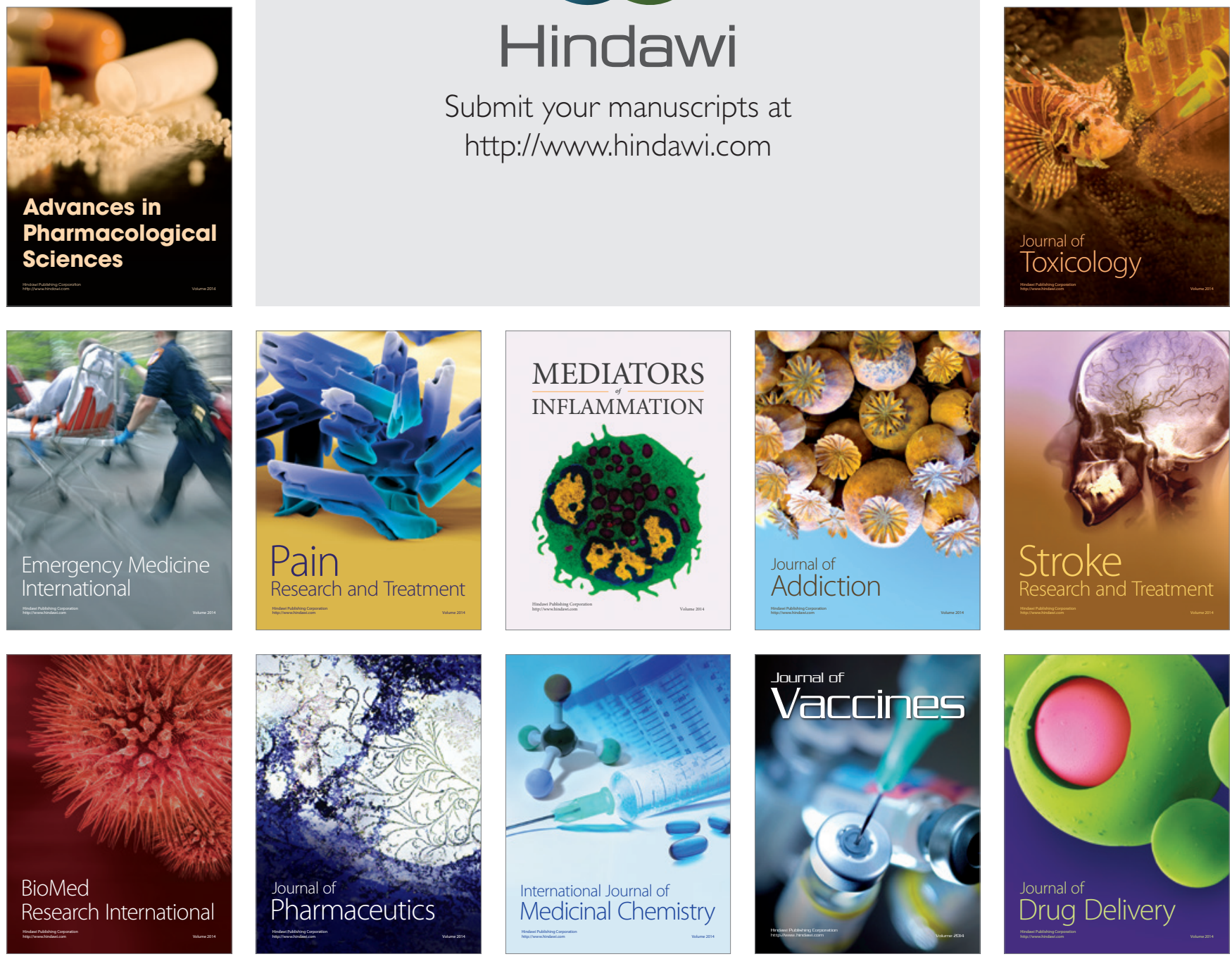